\title{
How to stop the snowball growth? A way for sustaining public debt over generations
}

\author{
Ion-Lucian, CATRINA, \\ Associate Professor, PhD \\ "Dimitrie Cantermir" University, Bucharest \\ cionlucian@gmail.com
}

\begin{abstract}
Why public debts are growing so fast in most developing countries, like a dangerous snowball which is growing and growing and no one can stop it? It is only a negative relation between high debt and real growth of economy? How can we definitively remove the Ricardian anxiety which called debt a "terrible scourge"? These are only few questions asked in the last century in relation with debt "overhang" not only by scholars, but by governments as well. This paper aims to answer to other questions like: Why debt's rate grows faster than GDP? Why governments borrow? For current spending or for public investments? Who should benefits current loans? Who should pay for them and when? How should be the taxation along the economic cycle: neutral or countercyclical? Need we a model to sustain the public debt over generations, or it is good enough to maintain a good ration between real GDP growth and debt and that's it?
\end{abstract}

Keywords: public debt; sustain; generations, intertemporal

JEL Classification: E10, E62

\section{Introduction}

Four years ago I have published an appreciated study addressing to the equity of public debt over the generations. In that article I have started from the assumption that the public debt used for public investment which produce social and economic benefits is not at all a bad decision. I had assumed that the public debt should not be seen as a dangerous mistake if it results from capital accumulation, from investments with high yields in present and in the future or as a result of short-term shocks of the economy which will be offset as soon as the growth resumes. I also considered that the stock of public debt should be managed so that the tax burden of future generations has not to be higher than the present generation. In respect to who should reimburse and when, one of 
the conclusions was that expenditure for capital accumulation should be covered when the benefits will occur (Catrina, 2013).

Unfortunately, in the last four years, none of the world's economies has adopted a sustainable rule, a kind of "golden rule" in order to remove governments' temptation to excessively borrow for current spending and to delay the payment of loans to next generations. The government borrowing still represents the single option of political governments in respect with the other alternative to cover current spending: through increasing current taxation or to adjust the spending to permanent government revenues level. This argument is strengthened by the most part of national fiscal policy, which, with few exceptions, governments never run budget in surpluses or almost balanced. So, the debt stock increase is unavoidable, affecting the interest's level and the real growth of the GDP as well. The strongest argument of politicians is linked to growth considering that - we will never have a debt problem as long as the real economy grows faster than debt, missing the fact that the economy is cyclical and always in electoral years the debt always grows quickly than the real GDP. So, we cannot disconnect the fiscal policy or the alternatives which have to conduct to a sustainable management of the public debt from political factors "political distortions" - understanding by this the predisposition of politicians to engage government spending over the economy's capacity to fund it, generating every year excessive deficits, even in periods of economic boom (Gavin \& Perotti, 1997; Talvi \& Vegh, 2005; Alesina \& Tabellini, 2005; Iron \& Bivens, 2010).

In the EU, after the adoption of Treaty on Stability, Coordination and Governance in the Economic and Monetary Union, only few member states reach the balanced budget rule and the medium-term objectives, regarding the lower limit of a structural deficit of $0,5 \%$ of the gross domestic product at market prices. Every single state have used different fiscal or budgetary policies in order to resume national economy, stimulating higher deficits and higher debts, growing the EU medium debt over $85 \%$ to EU GDP.

In September 2016, the International Monetary Fund estimates that the global debt already exceeds 152 trillion dollars. Moreover, this estimation reveals that the most of developed economies borrowed heavily in the boom years than in recession time. IMF also invalidates its own estimations on current and future growth on most developed economies. The permanent overestimation of real growth of GDP and the underestimation of the debt accumulation in the boom time are two arguments that request us to find out a sustainable model to manage public debt on current time and across the next generations. 
In this paper we hope to find out one way, one model, to sustain public debt over generations using fiscal and monetary tools and answering simultaneously to additional requirements: peoples' right to health care; children's right to go to school; a minimum standard of life; the economies are cyclical; today and in the future, the main sources of growth depends on human capital, innovation and technological progress; the needs of price stability without excessively using inflation to overcome debt and so one.

\section{Summarizing the main debt theories and fiscal policy over the cycle}

There are more than two centuries from the rising of the first theories regarding the economic role of the free market and the intervention of governments through tax and spending. From Ricardo to Pigou, the budget deficits and governmental debt accumulation was strongly rejected, considering that a well conducted economy must cover current spending by current taxes and the public spending should be imperatively flexible to revenues. In the late 20s, Pigou admits that deficits and loans for capital production or capital accumulation or for covering the negative effects of wars or natural disasters may be temporary made.

How should be the government policies along the economic cycle was questioned next to the great depression - countercyclical (Keynes, 1936) - or neutral (Barro, 1979). It is true that the debt issue begins to spend greater attention from theoreticians next to the WWII, in respect of huge war debts accumulation. But, as the economic literature distinguishes itself, it is a fundamental difference between public debt accumulation during the war and the debt accumulated in the peacetime and economic growth. Moreover, after the WWII we are dealing with unprecedented growth of public spending, the share to GDP grew from around $20 \%$ after WWII to over $45 \%$ in present (Schuknecht \& Tanzi, 1997).

From the 60s until the latest financial crisis 2011, the high stock debt accumulation was analysed in few directions regarding:

- The negative effects of high public debt on real growth of GDP - debt intolerance - Modigliani, Barro, Meade or Pisani-Ferry, Reinhart, Rogoff. So, their researches tell us that beyond a certain level of the debt, it becomes unmanageable for governments and it is a strong disruptive for growth and inflation.

- The debt burden or "debt overhangs" - Meade, Buchanan, Wagner, Modigliani, Krugman - request an optimal distribution of loans, between 
external/domestic lenders, which should not conduct to an wealth transfer to foreign creditors or to crowding out effects on internal market.

- Debt maturity and fiscal policy - Buchanan, Wagner, Musgrave - the opportunity cost is the value of private goods, which are given in exchange for public goods, which makes possible government debt; Who should pay the debt and when through an increase taxes? The beneficiaries of public services should pay for them themselves and not future generations (Musgrave, 1997).

- Generational accounting -Kotlikoff, Auerbach, Ferr, Leibfritz,Cardarelli, Sartor, Catrina -intergenerational equity of public debt - using intertemporal budget constraints and intergenerational balance Gap.

- The "kiss of death" of debt stabilization or debt reduction -Alesina, Carloni, Lecce - political consequences of strong fiscal adjustments will be reflected in the loss of votes and the loss of power.

- Stronger fiscal rules -Wyplosz, Blanchard, Balassone, Giavazzi - a better coordination of fiscal and monetary policies; separation of budgetary expenditure: ordinary expenses and capital expenditures.

In the same time, in the past century we can easily find a strong concern for defining new set of fiscal indicators which have to improve the management of fiscal policy and to conduct to debt stabilization. For example, the one of the former chief economists of IMF speaks about the necessity to discover a new and more accurately indicator of the sustainability of fiscal policy - structural deficit (Hagemann, 1999). Next to the Hagemann, Muller and Price, Blanchard, Mendez \& Lamo, Dalsggard \& Serres tried to find out the easiest and the most precise way to estimate the structural balance, in order to eliminate the cyclical mirage of growth.

\section{Is the "golden rule" obsolete? What role plays public investments?}

As we already said, splitting the public expenditure in current spending and spending for public investment is not at all a new idea. While the budget for current spending must be balanced or in surplus, the budget for investments may run on manageable deficits, as the social an economic return will quickly offset the investment expenditures. This paradigm arises from the first exception assumed by Pigou, which firstly admits that spending for investment cannot be seen dangerous. Despite the fact that the benefits of this budgetary rule were well known from the 60s, the "golden rule" was effectively implemented by 
British Treasury in the late 90s only for few years (1997-2009) but unfortunately it was abandoned under political pressures, considering that British government had manipulated this rule for allowing more borrowing:

\section{Golden rule$$
d-i=g_{c}-t+r b \leq 0
$$

Where $d$ is the seasonally adjusted deficit, $i$ represent net investment as a percentage of GDP, $g_{c}$ government spending, including transfers and replacements of capital, $t$ represent taxes, $r$ - short-term interest rate and $b$ is the stock of public debt relative to GDP.

In the EU, after the failure of the Stability and Growth Pact in EMU (1996), the new Treaty on Stability, Coordination and Governance in the Economic and Monetary Union (2012) resume the budgetary rule which run close to balance or in surplus. Moreover, the new treaty changes the focus on structural deficit, setting a new fiscal convergence criterion, keeping the Maastricht conditions unaffected:

$$
D s=(V s t-C s t) \leq 0,5 \% \text { from } G D P
$$

Where $\boldsymbol{D} \boldsymbol{s}$ - structural deficit, $\boldsymbol{V} \boldsymbol{s}_{\boldsymbol{t}}$ structural revenues and $\boldsymbol{C s}_{t}$ structural spending

We have to admit that the new rule helps to a better fiscal consolidation into member states, to debt stabilization, but so far none of the countries did fall within this target. Using the argument that the economic recovery would be stimulated by significant public investment, most of EU members have extended the public spending waiting higher growth rates. But the expected high growth does not want to appear any more, and those who took these decisions rhetorically ask themselves what and where they were wrong.

In the past century, by public investments, which can stimulate the growth, all the economists understood huge spending on transport infrastructure, on communications, energy or agricultural infrastructure. Today, most part of developed economies has already high speed infrastructure for merchandises transportation, high speed communications, efficient systems of 
energy and good productivity on agriculture. So, spending more in these sectors seems to be no so useful for growth or the multiplication effects are not the same like two decade ago. Analysing the developed economies seems to be more than manifest that emergent sectors for public investments are different today: education, applied research, environment, ageing population, faster communications for new technologies. Unfortunately Member States not paid adequate attention for founding these sectors; EU has constantly lost competitiveness as a result of not enough research and innovation embedded in European products.

\section{Starting the construction of a new way to sustain public debt on long term}

A sustainable model for managing public debt over the generation, without having negative effects on real growth and on future generation by taxation, should take into account more than fiscal variables. In the past years there have been several attempts to reach a sustainable model in order to find out the best way so that future generations will not be took the right to a wealthy life and not be transferred the burden of payment of the public debt through higher taxes.

For example, Auerbach and Kotlikoff use in their model fiscal indicators and introduce demographic variable for the generational accounts. So, they aggregates the present value of the remaining lifetime (net payments) of existing generations and the present values of the generational accounts of future generations, relative of the year of birth (Auerbach \& Kotlikoff, 1999).

Starting from the same view, Cardarelli and Sartor developed a more complex model on the Italian economy, which best reflects the way in which budgetary policies affect economic growth, savings and capital accumulation (Cardarelli \& Sartor, 2000).

The common point of the two models is the new concept called intertemporal budget constraint. This concept requires that "the future net tax payments of current and future generations be sufficient, in present value, to cover the present value of future government consumption as well as service the government's initial net indebtedness". Auerbach and Kotlikoff underline that "the constraint does not assume that government debt is ever fully paid off, merely that the debt grows less quickly than the rate of discount-that it does not explode. Thus it is consistent with the long-run existence of government deficits, 
as long as these deficits are smaller than the amount needed simply to service the level of outstanding debt" (Auerbach \& Kotlikoff, 1999).

Intertemporal budget equation - Auerbach and Kotlikoff, 1999

$$
\sum_{k=t-D}^{t} N_{t, k}+(1+r)^{-(k-t)} \sum_{k=t+1}^{\infty} N_{t, k}=\sum_{s=t}^{\infty} N_{t, k} G_{s}(1+r)^{-(s-t)}-W_{t}^{g}
$$

Where $N_{t, k}$ represents stands for the account of the generation born in year $k$, meanwhile the index $k$ in this summation runs from $t-D$ (those aged $D$, the maximum length of life, in year 0 ) to $t$ (those born in year 0 ). On the left, $k$ represent the year of birth.

Starting from this model, Cardarelli and Sartor have added new variable like: labour productivity $g$, the net lifetime taxes for members of each successive future cohorts rise at the economy's rate of labour productivity growth,

Intergenerational Balance Gap - Cardarelli and Sartor, 2000

$$
I G G=\sum_{s=1}^{\infty} G_{t+s}(1+r)^{t-s}-W_{t}-\sum_{s=0}^{D} N_{t, t-s} P_{t, t-s}-\sum_{s=1}^{\infty} N_{t, t}(1+g)^{s} P_{t, t+s}(1+r)^{t-s}
$$

Unfortunately, the two models does not include any monetary variable, most helpful would be inflation or interest rate.

\section{Should we trust all IMF's recommendations on debt dynamics?}

Even if in his disclaimer The Practical Guide of Debt Dynamics, Fiscal Sustainability and Cyclical Adjustment of Budgetary Aggregates underline that the paper prepared by Julio Escolano does not represent the official position of IMF, we can easily recognize that most national policies implemented in the last decade in the countries which were financial assisted by IMF were conducted by this view. 
It is obviously that IMF cannot escape from his path dependency which resume to a purely accounting outlook on debt dynamic - debt ratio constant to GDP or no-Ponzi game condition.

The IMF specialist tried to analyse the problem intertemporal, but in respect with the intertemporal allocation. Escolano considers that the intertemporal allocation could be improved "if private agents consumed more now through borrowing at the low interest rate and rolled over their debt which would still decline as a ratio to their income, since growth exceeds the interest rate."He argued that, on historical basis, there were many "episodes during which the growt had justed interest rate was negative were accompanied by large credit expansions". This view is limitative and hazardous. On the other hand, IMF annalist spoke about intertemporal budget constraints, but limits the sustainability to the path of primary balances.

\section{Conclusions}

Today, the public debt should not worries the governments which use most part of financial resources in order to make their national economies more competitive, through a sustainable demographic policies avoiding ageing population and by stimulating the research and the innovation that must be the hard core of competitiveness.

Regarding the strong challenge of stopping the snowball of indebtedness, we cannot ignore the influence of political factors -governments are on political objective oriented - on fiscal discipline, because procyclical temptations is not any more a particularity of emerging economies. If we start from the hypothesis that the governments are without doubt conscientiousness, then we can easily find very useful and functional one model which must sustain the debt over generations.

We agree that along the time could be some variations on tax policy, but these should not become a burden transfer between generations if we agree a constant burden of fiscal policy. The models developed from Auerbach and Kotlikoff, and from Cardarelli and Sartor represent a good start for all economists or institutions to work out other models, may be more comprehensive, which must include more monetary and demographic elements. We have to not minimize the role of inflation on debt, the structure of loans by currency or the optimal use of workforce over the time. 


\section{References}

[1] Albu, L.-L., Pelinescu, E. (1999), Sustenabilitatea datoriei publice şi a deficitului bugetar, CRPE, nr. 4.

[2] Alesina, A., Carloni, D., \& Lecce, G. (2011). The Electoral Consequences of Large Fiscal Adjustments, NBER Working Papers, Cambridge.

[3] Altar M., et al. (2008). Modeling the Economic Growth in Romania. The Influence of Fiscal Regime, Romanian Journal of Economic Forecasting, nr. 4, p. 146-160.

[4] Auerbach, A. J., Gokhale, J., \& Kotlikoff, L. J. (1991). Generational accounts - a meaningful alternative to deficit accounting, No. w3589, National Bureau of Economic Research, pp. 55110, Chapter in Tax Policy and the Economy, Volume 5, Edited by David Bradford.

[5] Balassone, F., Franco, D., \& Zotteri, S. (2004). Public Debt: A Survey of Policy Issues, Bank of Italy, Research Department, Public Finance Workshop, 1-3 April 2004, Perugia.

[6] Barro T. R. (1979). On the Determination of Public Debt, The Journal of Political Economy, Vol. 87, No. 5, Part 1 (Oct., 1979), pp. 940-971.

[7] Blanchard, O.J. (1985). Debt, Deficits and Finite Horizons, Journal of Political Economy, Nr. 93, pp. 223-247.

[8] Boissinot, J., L'angevin, C., Monfort, B. (2004). Public Debt Sustainability: Some Results on the French Case, Institut National de la Statistique et des Etudes Economiques.

[9] Buchanan J.M. \& Wagner R.E. (1958). Public Debt in a Democratic Society, American Enterprise Institute for Public Policy Research, Washington.

[10] Cardarelli, R., \& Sartor, N. (2000), Generational accounting for Italy, Banca d'Italia, Fiscal Sustainability, pp.501-558, available at https://www.bancaditalia.it/pubblicazioni/altri-atticonvegni/2000-fiscal-sustainability/501-558_cardarelli_and_sartor.pdf?language_id=1

[11] Catrina, I. L. (2013). Intergenerational Equity of Public Debt, European Journal of Science and Theology, 9(2), pp. 167-174.

[12] Escolano, J. (2010). A Practical Guide to Public Debt Dynamics, Fiscal Sustainability, and Cyclical Adjustment of Budgetary Aggregates, IMF.

[13] Hagemann, R. (2012). Fiscal Consolidation: Part 6. What Are the Best Policy Instruments for Fiscal Consolidation?, OECD Economics Department Working Papers, No. 937, OECD Publishing.

[14] Hagemann, R. (1999). The Structural Budget Balance. The IMF's Methodology, IMF.

[15] Kotlikoff, L. J. (1987). Intergenerational transfers and savings, National Bureau of Economic Research. NBER Working Paper No. 2237 (Also Reprint No. r1311).

[16] Krugman, P. (1988). Financing vs. Forgiving a Debt Overhang, National Bureau of Economic Research, Cambridge. Working Paper no. 2486 available at https://core.ac.uk/download/pdf/6708406.pdf

[17] Meade, E. J. (1958). Is the National Debt a Burden?, Oxford Economic Papers, New Series, Vol. 10, No. 2 (Jun., 1958), pp. 163-183.

[18] Musgrave, A. R. (1997). Reconsidering the Fiscal Role of Government, The American Economic Review, Vol. 87, No. 2, pp. 156-159.

[19] Pigou, C. A. (1929). A Study in Public Finance, New York: St. Martin's Press Inc. 
[20] Reinhart, M. C.,\& Rogoff, S. K. (2010). Growth in a Time of Debt, National Bureau of Economic Research, Cambridge. American Economic Review: Papers \& Proceedings 100 pp. 573-578.

[21] Schuknecht, L. \& Tanzi, V. (1997). Reconsidering the Fiscal Role of Government: The International Perspective, The American Economic Review, Vol. 84, Nr. 2, pp.164-168.

[22] Wyplosz, C. (2012). Fiscal Rules: Theoretical Issues and Historical Experiences, NBER Working papers, Chapter in NBER book Fiscal Policy after the Financial Crisis (2013), Alberto Alesina and Francesco Giavazzi, editors, pp. $495-525$. 